\title{
Developed Countries' (DC) Buyers Apply Higher Levels of Power over the Exporters from A Country such as Pakistan: A Perceptual Study
}

\author{
Muhammad Ehsan Malik*
}

\begin{abstract}
The power aspect in conceptualising importer-exporter interaction is very critical, but few studies are available concerning this issue in the context of export distribution channels. This article explores the powerrelated dimension of importer-exporter interaction.

An effort has been made to discern the pattern of perceptual differences between a number of importer-exporter pairs. It has been found that broadly speaking, the importer exercises higher levels of power over the exporter rather than vice-versa. But the perceptual differences between the importer and exporter do not follow a systematic pattern. Research efforts have significant implications for the exporters' community, generally in developed and particularly in developing countries such as Pakistan.
\end{abstract}

\section{Introduction}

Power, a much broader concept than authority, is the ability of individuals or groups to induce or influence the beliefs or actions of other persons or groups (Koontz and Weihrich, 1993). Research with regard to export marketing has mainly focussed on such broad areas as: export strategies (Baker and Abou-Zeid, 1982, Crick, 1995); export initiations (Czinkota, 1994); the impediments and parameters related with export success (Czinkota and Ricks, 1983, B. Ramaseshan and Geoffery N. Soutar, 1996); export development models (Bilkey and Tesar, 1977, Cavusgil, 1980, Cavusgil \& Yeo, P.L., 1994).

On the other hand, behavioural aspects related to export marketing channels have been largely ignored in Pakistan. Relatively little attention has been given in the marketing literature to export from less developed countries (LDCs) such as Pakistan, despite the fact that export development of manufactured products constitutes a vital input to enhancing their industrialisation and in turn, improving their economic outlook. The issue of power has been focused on the understanding of distribution channels as

\footnotetext{
* The author is an Assistant Professor at the Hailey College of Commerce, University of the Punjab, Lahore.
} 
behavioural systems in this article. Effort has also been made to analyse importer-exporter interaction and to identify the underlying pattern of perceptual differences between the two parties.

\section{Power}

The general concept of power stipulates the ability to make someone acquiesce to doing something that he or she would not have done. In the marketing channels' paradigm, power is defined as a member's “ability to control the decision variables in the marketing strategy of another member in a given channel at a different level of distribution". In this paradigm it implies an importer's ability to influence the behaviour of an exporter as "the mechanism by which the channel is organised and orderly behviour preserved” (French, Jr. and Raven, 1978).

Some marketing analysts view the above behavioural paradigm as synonymous with power. However, most scholars discriminate between these concepts, where power is considered "the ability to alter..." whereas influence or control refer to "the actual changing... resulting from the application of power" (Butaney and Wortzel 1988).

In this study, it is the exercised/unexercised power framework that is adopted. The exercised power is the control or actual alteration of another's behaviour, whereas unexercised power is associated with the ability to control or alter another's behaviour (Gaski 1984). It is clear that in channel relationships there is an imperative for each party to exercise mutual power in the interaction with its channel partners, as channel members must take each other's efforts into consideration when they attempt to achieve their own objectives (Frazier 1983).

\section{Review of Literature}

By analysing the association between channel control and success, Ahmed has (1977) revealed:

- That the exporter did not practise tight control over the importer

- And that there was very weak interaction between the extent of the exporter's degree of control and the importer's market penetration.

Nevertheless, it should be noted that Ahmed's attempt can be regarded as simplistic in both theoretical and methodological terms. In an empirical study, Leonidu (1989 \& 1995) attempted to conceptualise the pattern of behviour by indigenous manufacturers of consumer products 
based in developing countries, in the context of their working relationship with importers in developed countries.

It was established that the importer exercised higher levels of power in areas concerning the marketing side of the business association, while the exporter confined its exercised power to the production side. The importance of this research lies in the fact that it provides considerable guidance in the development of effective models for further research in the field.

\section{Hypotheses development}

It has been argued that indigenous manufacturers in LDCs possess low marketing skills, since marketing is viewed as a marginal function by the management of the firms (Kaynak and Hudana 1987). Such manufacturing firms are unlikely to successfully market their products abroad, particularly in developed countries. They rely mainly on their own policies and capabilities that result in the following factors:

- Short-term marketing plans;

- Cost-based pricing;

- Limited promotional activities;

- Ineffective marketing research (Kinsey 1988);

- And, 'bad habits' developed by operating in a domestic market which is characterised by 'sellers' conditions' in many sectors (Malhotra and Leonidou 1988, Frazier et al. 1989).

On the other hand, there is evidence that the developed countrybased importer plays a crucial role in the decision making process with regard to the strategic marketing issues associated with imported products from the LDC's framework. The importer, for instance, dominates on such issues as:

- Product design and Packaging,

- Quality control by inspecting the finished goods (such as ISO 9000),

- Inventory levels,

- Final selling price,

- Promotional activities and so on. 
114 The Lahore Journal of Economics, Vol.5, No.1 developed:

Based on the above premises, the following hypothesis can be

In the interaction between Pak Exporters and Developed Countries' (DC) Buyers, the importers apply higher levels of power over the exporters, in their mutual relationship.

Checkland (1981) demonstrated very rightly that people observe the same reality from the perspective of their individual world view depending on their past experience. Similarly, one would expect the exporter and importer to have a differential in their perception with respect to the exercised power in the association. This can be ascribed to in the different:

- Ethnic origins and backgrounds,

- Norms and values,

- And importer-exporter interaction.

It has also been speculated that in a channel interaction one member's perception of power, conflict, satisfaction, etc., will be inversely related to the perception reported by the other party (Gaski, 1984). Thus,

In the interaction between Pakistani Exporters and Developed Countries' (DC) Buyers, there are perceptual differences between the importers and exporters, with regard to exercised power. The one party's perception of the level of exercised power is diametrically different to that reported by the other party.

\section{Methodology}

A model can now be constructed comprising a developing country such as Pakistan and a DC. Any DC country is a typical developed country significantly involved in import activities from many countries, and is also considered a major market for a country such as Pakistan. On the contrary, Pakistan is a very small and less developed country highly dependent on its trading activities, especially with the developed countries.

Since only exercised power affects another's behaviour, a number of variables were employed to assess the aspect of exercised power. The final list of items was developed with the help of five export managers and two academicians familiar with research on channel behaviour. Exercised power was operationalised as a member's degree of participation in decision making on a number of important issues of his/her partner. The questionnaire of two forms was pre-tested in personal interviews with seven sales managers in 
Pakistan and three DC importers (e.g. from UK, Germany and Holland were interviewed through friends) in an attempt to ensure that the instrument was as reliable as possible.

The sampling frame of Pakistani exporters was identified from the Karachi and Lahore Chambers of Commerce and Industries and Export Promotion Bureau (EPB) of Pakistan, while that of the DC importers were identified from the Trade Information Directory published by ITC/UNCTAD/ GATT with regard to import Promotion Offices (IPOs) in EU countries. All firms in each sampling frame were requested to take part in the study. The overall usable sample included 34 Pakistani exporters and 13 DC importers responded. The product samples involved in the study were:

- Textile manufactured products,

- Leather garments,

- Sports goods,

- $\quad$ Surgical instruments

\section{Data collection}

In collecting the data, the key informant technique was employed. However, it has been argued that this technique has certain limitations associated with the complexity of the social judgements involved, positional bias, and ignorance of facts, which in turn can introduce considerable measurement error. In view of these deficiencies, a series of measures were taken to minimise the potential for systematic and random sources of errors as follows:

- Information collected about a specific interaction in each case,

- Interviewers were requested to check the facts with other company personnel,

- Interviewers had to determine relevant marketing policy decisions and contact with appropriate individuals, identified by the importers and exporters.

The fieldwork was conducted in two stages. The exporters' data were collected in Pakistan during 1996, while DC importers' data were collected during October 1995-February 1996. 
116 The Lahore Journal of Economics, Vol.5, No.1

\section{Hypothesis 1}

Power variables (e.g. packaging, products covered, final selling price, promotional activities, transportation methods, inventory levels, unit ordered mix, sales force organisation, territorial and customer restrictions, and marketing research). Based on the perception of Pakistani exporters, it was revealed that in present business interactions DC importers exercise higher levels of power in those decision making areas which are related to the power variables. On the contrary, Pakistani exporters were found to prevail over the DC importers in the decision making process associated with the following four areas:

- Product quality,

- Quality control (ISO 9000),

- Manufacturing process,

- Payment terms.

Joint basis decisions between the exporters-importers in the other marketing areas, in accordance with the results, were shown as under:

- Product design and style,

- Brand name,

- Selling/purchasing price,

- Minimum order size,

- Delivery schedules,

- Trading with other DC importers.

The DC importers were found dominant in the interaction with the Pakistani exporters in the following areas:

- Large size of the importer's firms,

- Strong financial positions,

- Proximity to the market,

- Access to a large number of alternative exporters from LDCs, 
- Entailing low degrees of dependence on the Pakistani exporters' habits,

- Superior marketing capabilities developed by operating in an "export market framework".

\section{Hypothesis 2}

The existence of perceptual differences between the importerexporter in the pairs studied adds to empirical evidence by research, that, by carrying out inter-group comparisons, a "conflict gap" was identified between the perceptions of UK manufacturers and those of their German intermediaries. In this research study, the perceptual gaps can be explained by differences in the task that each member had to perform in the interaction activity, by the fact that the exporters and importers appeared to have different backgrounds in terms of:

- Values and Norms,

- Political and Economic,

- Socio-Cultural and Technological Factors.

The above factors, in turn, have affected the perceptual as well as behavioural outcomes accordingly.

This study described that in general, the interaction was governed by imbalance of power exercised by DC importers over the Pakistani exporters. The sound market knowledge and superior marketing skills of the DC importers were found to be complimentary to the production capabilities of the Pakistani exporters.

As a result, full acceptance of Gaski's speculative hypothesis that exercised power will decrease satisfaction and increase channel conflict may substantially be questioned, as a result of the exercise of expert power in the interaction activity.

\section{Conclusions}

The aim of this article was to study the working interaction of Pakistani exporters with DC importers, and to shed light on the magnitude and pattern of potential perceptual gaps between that two parties, in the context of exercised power.

The study has described that DC importers, overall, exercise higher levels of power over Pakistani exporters. It was also revealed that in the 
majority of cases the examined parties were characterised by mutual perceptual gaps but such identified gaps had no discernable pattern.

Pakistani exporters need to recognise that the structural characteristics of foreign markets are different to those prevailing in the domestic markets, hence implying that they should accordingly be treated differently. Pakistani exporters may find advantages in adopting an active export orientation with a planned, organised and systematic approach in carrying out export activities.

Opportunistic and unsystematic involvement may result in underexploitation of the overseas market potential and may become a major obstacle to such exporting firms. Pakistani exporters appear to be unwilling or, sometimes, unable to contribute to a joint marketing programme with overseas customers which would include:

- Marketing research projects,

- Selling policies and sales force training,

- Packaging characteristics and,

- Promotional activities.

Pakistani exporters should direct their efforts towards establishing more joint decision-making on marketing programmes and possibly take the initiative in some other aspects such as:

- A new product development process,

- Product design and style,

- Quality standards (ISO 9000),

- Packaging features and,

- Brand recognition.

It may sometimes be difficult to draw general conclusions about individual phenomena when the subjects studied belong to a variety of industrial sectors, with its own experiences and configurations, as well as with particular strengths, weaknesses, opportunities, and threats (SWOT analysis) in a specific market framework. Finally, the reality of this article is concerned with both sides of the international trading equation, e.g., the exporters and the importers. 


\section{References}

Ahmed, A. A., Channe1 Control in International Markets, European Journal of Marketing, I, Fall, 1977 pp 327-335.

Baker, M. J. and Abour-Zeid, E. D., 1982, Success Exporting-An Analysis of performance and practice of the 1980 Queen's Award Winners for Export Achievement, Glassgow, Westburn Publishing Ltd.

Bilkey, W. J. and Tesar, G., The export behaviour of small-sized Wisconsin manufacturing firms, Journal of International Business Studies, 8, Spring/Summer, 1977, pp 93-98.

Brown, J. R. and Frazier, G. L., 1978, The application of channel power: Its effects and connotations. In: Research Frontiers in Marketing: Dialogues and Directions. (Ed.) Jain, S.C. Chicago, American Marketing Association, pp 260-270.

Butaney, G. and Wortze1, L. H., Distributor power versus manufacturer power: The customer role, Journal of Marketing, 52, January, 1988, pp 52-63.

B., Ramasesh and G. N., Soutar, Combine Effects of Incentives and Barriers on Firms 'Export Decisions' International Business Review, Vol. 5 No. 1, 1996.

Cavusgil, S. T. and Yeoh, P. L., Public Sector Promotion of U.S. Export Activity: Review and Directions for the Future, Journal of Public Policy \& Marketing, Vol. 13(1), 1994.

Checkland, P., 1981, Systems Thinking, Systems Practice, New York, John Wiley and Sons.

Crick, D., An Investigation into the Targeting of UK Export Assistance, European Journal of Marketing, Vo1. 29(8), 1995.

Czinkota, K. R., 1981, The export development process. A validation inquiry. In: Proceedings of European Academy for Advanced Research in Marketing. (Ed.) Larsen, H. H. and Heede, S. Copenhagen, pp 1121-1139.

Czinkita, M. R. and Johnston, W. J., 1981, Segmenting US firms for export development, 9, pp 353-365. 
Czinkota, M. R. and Ricks, D. A., The use of a multi-measurement approach in the determination of company export priorities, Journal of the Academy of Marketing Science, 11, 1983, pp 283-291.

Gaski, F., The Theory of Power and Conflict in Channels of Distribution, Journal of Marketing, Vol. 48, summer 1984, pp 9-29.

John R. P. French, Jr. and Bertram Raven, 1978, The Bases of Social Power in Walter E. Nattemeyer (eds.), Classics of Organisational Behaviour Oak Park, iii.: Moore Publishing Company.

Kaynak, E. and Hudanah, B. I., Operationalising the Relationship between Marketing and Economic Development: Some Insights from LessDeveloped Countries, European Journal of Marketing, Vo1. 21, No. 1, 1987, pp 48-65.

Kinsey, J., 1988, Marketing in Developing Countries, Macmillan Education, London.

Koontz, $\mathrm{H}$ and Weihrich, H., Management: A Global Perspective $10^{\text {th }}$ ed. McGraw-Hill, Inc. U.S.A., 1993.

Leonidou, L. C., Factors Affecting the Decision to Purchase from Third World Manufacturers; The British Experience, European Management Journal, Vo1. 6, No. 3, 1988, pp 262-268.

Frazier, G. L. and Kale, S. H., Manufacturer-Distributor Relationships: A Sellers' versus Buyers' Market Perspective, International Marketing Review, Vol. 6, No. 6, 1989, pp 7-26.

Import Promotion Offices (IPOs)., Various Export Worksheets, IPOs' Publications, Canada, 1995.

International Trade Center, Import Promotion Offices; A Directory of Import Promotion Offices and Similar Organisations that Provide Marketing Support to Exporters in Developing Countries. ITC/ UNCTAD/GATT, Geneva, 1995.

Export Promotion Bureau, Export Marketing Development Fund, Activities and Achievements, Karachi, 1995. 